\title{
Effect of subsequent two short-term, short-term, and long-term progestagen treatments on fertility of Awassi ewes out of the breeding season*
}

\author{
Nihat ÖZYURTLU ${ }^{1}$, S.Serhan AY ${ }^{2}$, İbrahim KÜÇÜKASLAN ${ }^{1}$, Örsan GÜNGÖR ${ }^{3}$, Selim ASLAN ${ }^{4}$ \\ ${ }^{1}$ Department of Obstetrics and Gynecology, Faculty of Veterinary Medicine, University of Dicle, Diyarbakir, Turkey; ${ }^{2}$ Department \\ of Obstetrics and Gynecology, Faculty of Veterinary Medicine, University of Ondokuz Mayis, Samsun, Turkey; ${ }^{3}$ Department of \\ Obstetrics and Gynecology, Faculty of Veterinary Medicine, University of Kafkas, Kars, Turkey; ${ }^{4}$ Department of Obstetrics and \\ Gynecology, Faculty of Veterinary Medicine, University of Ankara, Ankara, Turkey.
}

Summary: The aim of this study was to evaluate the effectiveness of different treatment methods of progestagen with PMSG in Awassi ewes out of the breeding season. A total of 48 ewes were divided into four groups equally. In Group I, vaginal sponges (30 mg fluorogestone acetate; FGA) were administered to ewes for seven days; afterwards vaginal sponge removal at the end of $7^{\text {th }}$ days and new vaginal sponge replaced for seven days in the same group. Vaginal sponges were administered for 7 days and 14 days in Group II and Group III, respectively. Group IV (Control) served as control group. In all experimental groups, 500 IU PMSG was given at sponge removal. Parameters such as estrus response rate, pregnancy and lambing rates, interval from sponge withdrawal to onset of estrus, duration of estrus and fecundity were evaluated. There were no significant differences in terms of estrus response rate, pregnancy rate, lambing rate, and fecundity between the Group I, II and III ( $p>0.05)$. In addition to this, any difference in the duration of estrus was not observed in all groups. However, variations in the interval from sponge removal to estrus was found significant $(\mathrm{p}<0.05)$ differences between Group II $(53 \pm 3.37 \mathrm{~h})$ and Group III $(41.5 \pm 1.81 \mathrm{~h})$. A slight increase in progesterone levels was observed after ram introduction, but a significant decrease in progesterone levels was found after two weeks from ram introduction $(\mathrm{p}<0.05)$.

It was concluded that there was no advantage of using two subsequent sponge treatments for achieving high progesterone concentration during treatment. In addition, short-term sponge treatment (7d) was found as effective as long-term sponge treatment in Awassi ewes out of the breeding season.

Key words: Anestrus, awassi, estrus response, ewe, progestagen

\section{Ardışık iki kısa süreli, kısa süreli ve uzun süreli progestagen uygulamasının üreme mevsimi dışındaki İvesi koyunlarının dölverimine etkisi}

Özet: Bu çalışmanın amacı, üreme mevsimi dışında İvesi koyunlarında PMSG ile birlikte farklı progestagen uygulamalarının etkinliğini araştırmaktı. Toplam 48 baş koyun 4 eşit gruba bölündü. Grup I, vaginal süngerler (30 mg FGA) koyunlara 7 gün süreyle uyguland1, daha sonra 7. günde çıkarılan süngerin yerine yeni sünger tekrar 7 gün süreyle yerleştirildi. Grup II ve Grup III'de vaginal süngerler sırasıyla 7 ve 14 gün uygulandı. Grup IV, kontrol grubunu oluşturdu. Çalışma gruplarının tümünde süngerlerin çıkarıldığ anda 500 IU PMSG yapıldı. Östrusa gelme oranı, gebelik ve kuzulama oranları, süngerin çıkarılmasından sonra östrusa gelme aralığı ve östrus süresi ile verimlilik gibi parametreler değerlendirildi. Östrusa gelme, gebelik ve kuzulama oranları ile doğurganlık açısından Grup I, II ve III arasında önemli bir farklılık bulunmadı. Buna ilaveten, tüm gruplarda östrus süresi istatistiksel açıdan farklı olmadı. Ancak, süngerlerin çıkarılmasından sonra östrusa gelme süreleri açısından Grup II (53 $\pm 3,37$ saat) ve Grup III $(41,5 \pm 1.81$ saat) arasında önemli farklılıklar bulundu $(\mathrm{p}<0.05)$. Koç katımından sonra progesteron (P4) seviyesi hafif arttı ama bu artışı takiben koç katımından iki hafta sonra azaldı $(\mathrm{p}<0.05)$.

Sonuç olarak, sünger uygulama sürecinde yüksek progesteron konsantrasyonu oluşturmak için ardışı olarak iki defa sünger kullanılması hiç bir avantaj sağlamadı. Buna ilaveten, üreme mevsimi dışındaki İvesi koyunlarında kısa süreli (7 gün) sünger uygulamasının uzun süreli uygulama kadar etkili olduğu bulundu.

Anahtar sözcükler: Anöstrus, ivesi, koyun, östrusa gelme, progesteron

\footnotetext{
* This study was supported by DÜBAP under project number 06-VF-17 (07-01-17).
} 


\section{Introduction}

Sheep and goat are the most conspicuous seasonal breeders among domestic farm animals. The evolutionary reason for this is undoubtedly that, in regions where climate and nutrition change throughout the year, offspring are born at the most favorable time to survive. The day length pattern has a dominant controlling influence on initiation and termination of breeding season $(2,3,13)$. Breeding ewes during anestrus season has relied on two general approaches; the use of the rameffect and progestagen-based treatments. Progestagens or its analogs with gonadotropin have been used to induce fertile estrus in anestrus ewes. Although advantages of progestagens, pregnancy rates of progestagen-synchronized ewes were lower during anestrus than during the breeding season $(4,11,18)$. Progestins can be administered by daily injections as a feed additive or intravaginal devices (5).

Intravaginal sponges have been the traditional treatment of choice for estrus synchronization in small ruminants during breeding season and anestrus. They are impregnated with progestagens which are more effective than natural progesterone at lower dose levels. Intravaginal sponges are generally inserted in the vagina for a period of 10 to 14 days and used in conjunction with PMSG, particularly for anestrus season, injected at time of sponge removal or $48 \mathrm{~h}$ prior to sponge removal $(6,9,25)$.

Progestagen treatment have widely used in sheep, traditionally by the use of intravaginal devices for long periods (12-14 days). However, recent studies showed that progesterone priming as short as 5-6 days is as effective as the traditional long-term priming to induce estrus with acceptable pregnancy rates during anestrus in sheep $(11,14,24)$. Long-term progestagen treatments are widely used in small ruminants to induce and synchronize estrus. A high percentage of animals showed estrus as a result of treatment, but fertility after progesterone treatment was lower than the fertility after a natural estrus. This low fertility rate has been attributed to changes in the hormonal milieu that results in an asynchrony between estrus and ovulation (17, 24). Treatment with low level progestagen for estrus induction reduces subsequent fertility (21). There are two explanations for this reduction of fertility, such as impaired sperm transport (1) and an extension of the lifespan of the ovulatory follicle (23). Short-term treatment provides exposure to higher average concentrations of progestagen during the treatment period. Such treatments ( 5 to $8 \mathrm{~d}$ ) have been effective in anestrus ewes (11). Administration of PMSG has long been used in conjunction with progestagen to stimulate reproductive activity in seasonally anestrous ewes.
Exogenous PMSG increases the incidence of estrus and ovulation (8). Zaiem et al. (26) were evaluated three doses of PMSG (300, 450 and 600 IU) with fluorogestone acetate (FGA) sponges during the anestrus season in ewes (26).

The aim of this study was to compare effectiveness of long-term, short-term and subsequent two short-term progestagen treatments (to achieve high progesterone level during treatment) combined with PMSG application for estrus induction out of the breeding season.

\section{Materials and Methods}

The experiment was carried out under natural conditions in the period from the second half of April to first week of May in the southeast of Turkey out of the breeding season. This region is situated at $37^{\circ} 55^{\prime} 01^{\prime \prime} \mathrm{N}$ latitude, and $40^{\circ} 16^{\prime} 46^{\prime \prime} \mathrm{E}$ longitude, and at an altitude of $660 \mathrm{~m}$. A total of 48 Awassi ewes (2-4 years old) were divided into four groups. Ewes were selected randomly. The ewes grazed on natural pasture all day and water was offered ad libitum.

The intravaginal sponges (30 mg FGA; Chronogest) administered to ewes for seven days in Group I; afterwards vaginal sponges removal at the end of $7^{\text {th }}$ days and new vaginal sponge replaced the same group for seven days. Vaginal sponges administered for 7 days and 14 days in Group II and Group III, respectively. Group IV served as control group (Fig 1). All ewes, including control group, received an intramuscular injection of 500 IU PMSG (Choronogest/PMSG) at sponge removal.

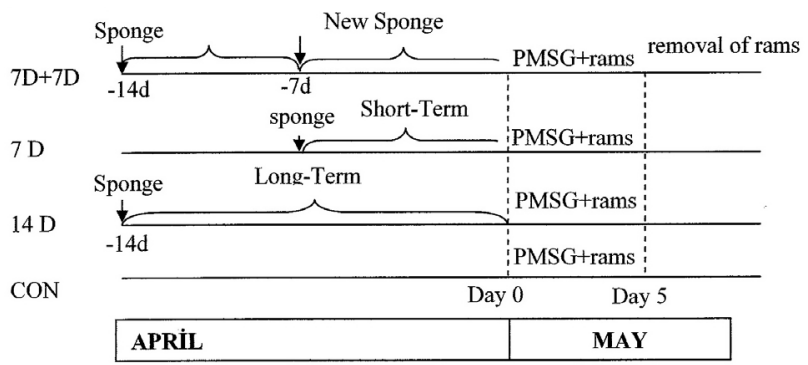

Figure 1. Schematic presentation of the study groups Şekil 1. Çalışma gruplarının şematik gösterimi

After withdrawal of sponges, rams were introduced and sexual receptivity was assessed by observing marks on the rump of the ewes at $12 \mathrm{~h}$ observation intervals for a five-day period. Commencement of estrous was defined as the time when the ewe first stood to be mounted by the ram. Duration of estrus was defined as the interval between the onset of estrus and the end of estrus. Estrous response rate (percentage of ewes in estrus), interval to onset of estrus from sponge withdrawal, duration of estrus, pregnancy rate (number of pregnant ewes/total number of ewes $x$ 100), lambing rate (number of lambs 
Table 1. Results of the fertility

Tablo 1. Fertilite bulguları

\begin{tabular}{|c|c|c|c|c|}
\hline Parameters & $\begin{array}{l}\text { Group I } \\
\text { (n: 12) }\end{array}$ & $\begin{array}{l}\text { Group II } \\
\text { (n: 12) }\end{array}$ & $\begin{array}{c}\text { Group III } \\
\text { (n: 12) }\end{array}$ & $\begin{array}{c}\text { Group IV } \\
\text { (Control) } \\
\text { (n: 12) }\end{array}$ \\
\hline Estrus response rate $(\%)$ & 100.0 & 91.6 & 91.6 & 25.0 \\
\hline Pregnancy rate $(\%)$ & 58.3 & 66.7 & 58.3 & -- \\
\hline Lambing rate $(\%)$ & $75(9 / 12)$ & $83.3(10 / 12)$ & $66.6(8 / 12)$ & -- \\
\hline Fecundity & $1.28(9 / 7)$ & $1.25(10 / 8)$ & $1.14(8 / 7)$ & -- \\
\hline Interval from sponge withdrawal to onset of estrus ( $h ; \mathrm{X} \pm \mathrm{SD}$ ) & $50.5 \pm 2.6$ & $53.0 \pm 3.4^{*}$ & $41.5 \pm 1.8^{*}$ & $43 \pm 3.6$ \\
\hline Duration of estrus $(\mathrm{h} ; \mathrm{X} \pm \mathrm{SD})$ & $31.9 \pm 1.4$ & $32.1 \pm 1.7$ & $33.1 \pm 1.6$ & $35.6 \pm 2.0$ \\
\hline
\end{tabular}

*: $\mathrm{p}<0.05 ; \mathrm{X} \pm \mathrm{SD}:$ mean \pm Standart Deviation

Table 2. Progesterone levels after ram introduction

Tablo 2. Koç katımı sonrası progesteron seviyeleri

\begin{tabular}{lcccc}
\hline P4 levels $(\mathrm{ng} / \mathrm{ml})$ & $\begin{array}{c}\text { Day 0 } \\
(\mathrm{X} \pm \mathrm{SD})\end{array}$ & $\begin{array}{c}1^{\text {st }} \text { week } \\
(\mathrm{X} \pm \mathrm{SD})\end{array}$ & $\begin{array}{c}2^{\text {nd }} \text { week } \\
(\mathrm{X} \pm \mathrm{SD})\end{array}$ & $\begin{array}{c}3^{\text {rd }} \text { week } \\
(\mathrm{X} \pm \mathrm{SD})\end{array}$ \\
\hline Group I & $0.46 \pm 0.03^{\mathrm{a}}$ & $2.94 \pm 0.39^{\mathrm{a}}$ & $2.42 \pm 0.18^{\mathrm{ab}}$ & $1.68 \pm 0.34^{\mathrm{a}}$ \\
Group II & $0.39 \pm 0.03^{\mathrm{a}}$ & $4.08 \pm 1.02^{\mathrm{a}}$ & $3.66 \pm 0.72^{\mathrm{b}}$ & $3.03 \pm 0.50^{\mathrm{b}}$ \\
Group III & $0.53 \pm 0.04^{\mathrm{a}}$ & $4.13 \pm 0.77^{\mathrm{a}}$ & $3.51 \pm 0.58^{\mathrm{b}}$ & $1.67 \pm 0.46^{\mathrm{a}}$ \\
Group IV & $0.50 \pm 0.06^{\mathrm{a}}$ & $2.24 \pm 0.60^{\mathrm{a}}$ & $1.55 \pm 0.32^{\mathrm{a}}$ & $0.72 \pm 0.10^{\mathrm{a}}$ \\
& $\mathrm{p}>0.05$ & $\mathrm{p}>0.05$ & $\mathrm{p}<0.05$ & $\mathrm{p}<0.01$ \\
\hline
\end{tabular}

$\mathrm{a}, \mathrm{b}, \mathrm{ab}$ : Different superscripts in the same columns indicate significant differences

born/total number of ewes x 100) and fecundity (number of lambs born/number of pregnant ewes) were evaluated in all groups. Pregnancy rate, lambing rate and fecundity were recorded after parturition.

Blood samples were collected weekly for 3 weeks on the day of ram introduction in all groups. The collected blood centrifuged immediately (3000 x g, $15 \mathrm{~min}$ ) and plasma was separated and stored at $-20^{\circ} \mathrm{C}$ until assessment of progesterone (P4) assays. Serum progesterone levels were assessed by radioimmunoassay (RIA) technique. The range of standards for progesterone (P4) was from 0.25 to $16.0 \mathrm{ng} / \mathrm{mL}$. Intra- and interassay coefficients of variations were $8 \%$ and $9 \%$ for $\mathrm{P} 4$ respectively (12).

Estrus response rate, pregnancy rate, lambing rate and fecundity were statistically analyzed using logistic regression analysis method. Descriptive statistics were used for the evaluation of estrus response rate and reproductive performance. Interval from sponge withdrawal to onset of estrus, duration of estrus and progesterone levels after ram introduction were analyzed by One-Way ANOVA while differences were tested by Duncan' test. The SPSS 13.0 statistics program was used to analyze the data (20). Differences were considered significant at $\mathrm{p}<0.05$.

\section{Results}

The estrus response rate, pregnancy rate, lambing rate, fecundity, interval from sponge withdrawal to onset of estrus and duration of estrus are presented in Table 1. There was no significant difference in the estrus response, pregnancy rate, lambing rate, fecundity and duration of estrus between the treatment groups. However, differences in the interval from sponge removal to onset of estrus was found to be significantly different between Group II and III $(p<0.05)$. The progesterone levels of all groups after ram introduction during three weeks were presented in Table 2 and, graphically in Figure 2.

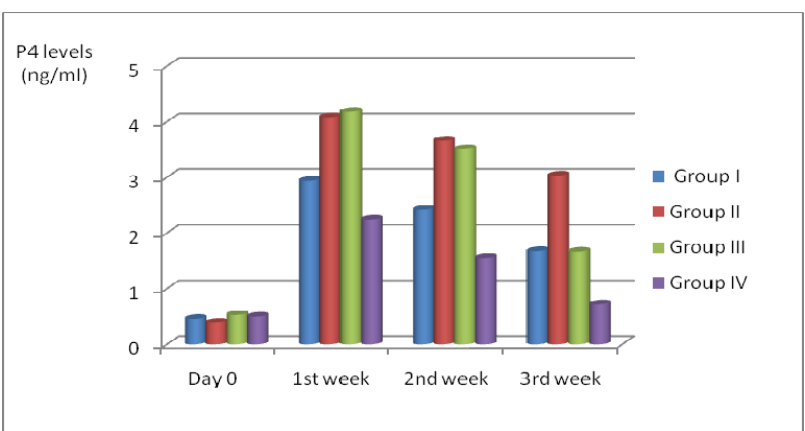

Figure 2. Graphic presentation of the progesteron levels after ram introduction

Şekil 2. Koç katımı sonrası progesteron seviyesinin grafik sunumu

\section{Discussion and Conclusion}

Short-term treatment of ewes with progestagen before ram introduction was adequate to induce fertile 
estrus (11). The short-term treatment achieves supraluteal levels of progesterone concentration with an acceptable pregnancy rate. In a study (16) it was determined that short-term protocol induces LH peak at $40 \mathrm{~h}$ and ovulation occurs $60 \mathrm{~h}$ after the end of progesterone treatment. Knights et al. (10) reported that a 5-d treatment with FSH stimulated fertile estrus as effective as a 12-d treatment with FSH. Short-term progestagen treatment shows higher progesterone levels at the time of device withdrawal. This procedure can be a good alternative to traditional procedures, due to permit more flexibility under field conditions. In addition to advantage of short-term intravaginal sponge treatment, treatment with low levels of progestagen for estrus synchronization reduces subsequent fertility (21). This reduction was explained via an extention of the lifespan of the ovulatory follicle, as a consequence of low levels of progesterone (23).

It was reported anestrous ewes that received progestrone injections for 3 or $6 \mathrm{~d}$, sponges for $6 \mathrm{~d}$ or feed containing melengestrol acetate for $8 \mathrm{~d}$ showed estrus after ram introduction (11). Ungerfeld and Rubianes (21) showed that short-term progestagen treatment was adequate to induce fertile estrus and, no difference in estrus response was observed when anestrus ewes are primed for 6 or 14 days, with intravaginal sponge treatments. Similar results were recorded with sponge treatment that containing lower levels of hormones than commercial sponges (7). Ustuner et al. (22) reported a $77.1 \%$ and an $88.2 \%$ incedence of estrus induction following short-term and long-term sponge treatment in Awassi ewes. No significant difference was observed in estrus response rate between Group I, II and III in this study. This is in consistent with the findings of researchers that mentioned above.

Some researchers $(15,24)$ reported that prolonged progesterone treatment has a negative effect on oocyte development. Long-term progestagen treatment results in subluteal progesterone level (15) and this phenomenon leads to increase the LH pulse's frequency, but the LH surge does not occur and result in persisting of the largest follicle (23).

Vinoles et al. (24) obtained higher pregnancy rate after short-term treatment compared to the traditional (12 d) treatment with PMSG at the time of vaginal sponge withdrawal. Ustuner et al. (22) reported that there were no significant differences in terms of pregnancy and lambing rates between the short-term and the long-term treatment groups. Ungerfeld and Rubianes (21) recorded $67.4 \%$ conception rate with short-term sponge treatment. The pregnancy rates were $66.7 \%$ and $58.3 \%$ and, lambing rate were $83.3 \%$ and $66.6 \%$ in short-term tratment (Group II) and long-term tratment (Group III) in this study, respectively. No significant difference was observed in this study which agrees with Ustuner et al. (22).

Ungerfeld and Rubianes (21) recorded as $46.2 \mathrm{~h}$ interval between removal of the sponge and onset of estrus with short-term sponge treatment. Ustuner et al., (22) reported that the interval between removal of the sponge and onset of estrus was longer in short-term sponge tratment $(73.3 \mathrm{~h})$ than in long-term sponge treatment (33.3 h). In this study, no significant difference was found between Group I and the other treatment groups. However, the onset of estrus was earlier in Group III $(41.5 \mathrm{~h})$ than Group II $(53 \mathrm{~h})(\mathrm{p}<0.05)$. Despite the recorded difference in term of onset of estrus in Group III and Group II, no significant difference was recorded in duration of estrus between all groups in this study. In addition of these results, it is reported that high doses of progestagen for estrus induction may increase interval between ram introduction and onset of estrus from ram introduction to estrus $(11,19)$.

In conclusion, this study demonstrated that the short-term progestagen treatment was as effective as the long-term treatment for induction of estrus. Thus, shortterm progestagen treatment procedure for induction of estrus can be a good alternative to traditional procedures (12-14 d).

\section{References}

1. Allison AJ, Robinson TJ (1970): The effect of dose level of intravaginal progestagen on sperm transport, fertilization and lambing in the cyclic Merino ewe. J Reprod Fertil, 22, 515-531.

2. Arthur HG, Noakes DE, Pearson H (1989): The oestrous cycle and its control. In: Veterinary Reproduction and Obstetrics. $6^{\text {th }}$ edition, W.B. Saunders Co., Philadelphia.

3. Bearden HJ, Fuquay JW (2000): The estrus cycle. In: Applied Animal Reproduction. $5^{\text {th }}$ edition, Prentice-Hall, Inc. Upper Saddle River, New Jersey.

4. Crosby TF, Boland MP, Gordon I (1991): Effect of progestagen treatments on the incidence of estrus and pregnancy rates in ewes. Anim Reprod Sci, 24:109-118.

5. Godfrey RW, Gray ML, Collins JR (1997): A comparison of two methods of estrus synchronization of hair sheep in the trophics. Anim Reprod Sci, 47, 99-106.

6. Godfrey RW, Collins JR, Hensley EL, Wheaton JE (1999): Estrus synchronization and artificial insemination of hair sheep ewes in the tropics. Theriogenology, 51, 985997.

7. Greyling JPC, Erasmus JA, Taylor GJ, van der Merwe S (1997): Synchronization of estrus in sheep using progestagen and inseminating with chilled semen during the breeding season. Small Rumin Res, 26, 137-143.

8. Husein MQ, Bailey MT, Ababneh JE, Romano JE, Crabo BG, Wheaton JE (1998): Effect of eCG on the pregnancy rate of ewes transcervically inseminated with frozen-thawed semen outside the breeding season. Theriogenology, 49, 997-1005. 
9. Iida K, Kobayashi N, Kohno H, Miyamoto A, Fukui Y (2004): A comparative study of induction of estrus and ovulation by tree different intravaginal devices in ewes during the non-breeding season. J Reprod Dev, 50, 63-69.

10. Knights M, Hoehn T, Lewis PE, Inskeep EK (2000): Effectiveness of intravaginal progesterone inserts and FSH to induce estrus and increase lambing rate in anestrous ewes. Abstract presented at the Midwestern Section ASAS and Midwest Branch ADSA 2000 Meeting, Des Moines, IA. Abstr, 216.

11. Knights M, Maze TD, Bridges PJ, Lewis PE, Inskep EK (2001): Short-term treatment with a controlled internal drug releasing (CIDR) device and FSH to induce fertile estrus and increase prolificacy in anestrus ewes. Theriogenology, 55, 1181-1191.

12. Kocamuftuoglu M, Vural R (2008): The evaluation of postpartum period in dairy cows with normal and periparturient problems. Acta Veterinaria (Beograd), 58, 75-87.

13. Lindsay DR (1991): Reproduction in the sheep and goat. 491-515 In: Reproduction in Domestic Animals, $4^{\text {th }}$ edition. Ed. Perry T. Cupps, Academic Press, Inc., California.

14. Menchaca A, Rubianes E (2001): Effect of high progesterone concentrations during the early luteal phase on the length of the ovulatory cycle of goats. Anim Reprod Sci, 68, 69-76.

15. Menchaca A, Rubianes E (2004): New treatments associated with timed artificial insemination in small ruminants. Reprod Fertil Develop, 16, 403-413.

16. Menchaca A, Miller V, Salveraglio V, Rubianes E (2007). Endocrine, luteal and follicular responses after the use of the short-term protocol to synchronize ovulation in goats. Anim Reprod Sci, 102, 76-87.

17. Pearce DT, Robinson TJ (1985): Plasma progesterone concentrations, ovarian and endocrinological response and sperm transport in ewes with synchronized oestrus. J Reprod Fertil, 75, 49-62.
18. Romano JE, Rodas E, Ferreira A, Lago I, Benech A (1996): Effect of progestagen, PMSG and artificial insemination time on fertility and prolificacy in Corriedale ewes. Small Rumin Res, 23, 157-162.

19. Rodriguez-Iglesias RM, Ciccioli NH, Irazoqui H (1997): Ram-induced reproduction in seasonally anovular Corriedale ewes: MAP doses for oestrous induction, ram percentages and post-mating progestagen supplementation. Anim Sci, 64, 119-125.

20. SPSS: Statistical package for social sciences for windows version 13.0, SPSS Inc, Chicago, IL. 2006.

21. Ungerfeld R, Rubianes E (2002): Short term priming with different progestogen intravaginal devices (MAP, FGA and CIDR) for eCG-estrous induction in anestrus ewes. Small Rumin Res, 46, 63-66.

22. Ustuner B, Gunay U, Nur Z, Ustuner H (2007): Effect of long and short-term progestagen treatments combined with PMSG on oestrus synchronization and fertility in Awassi ewes during the breeding season. Acta Vet Brno, 76, 391397.

23. Vinoles C, Meikle A, Forsberg M, Rubianes E (1999): The effect of subluteal levels of exogenous progesterone on follicular dynamics and endocrine patters during the early luteal phase of the ewe. Theriogenology, 51, 1351-1361.

24. Vinoles C, Forsberg M, Banchero G, Rubianes E (2001): Effect of long-term and short-term progestagen treatment on follicular development and pregnancy rate in cyclic ewes. Theriogenology, 55, 993-1004.

25. Wildeus S (2000): Current concepts in synchronization of estrus: Sheep and goats. Am. Soc. Anim. Sci., 1-8.

26. Zaiem I, Tainturier D, ChemLi J, Soltani M (1996): Vaginal sponges and different PMSG doses to improve breeding performances of Black Thibar ewes. Rev Med Vet, 147, 305-310.

Geliş tarihi: 16.04.2009 / Kabul tarihi: 26.07.2010 